\title{
PENINGKATAN KEMAMPUAN MEMAHAMI HUBUNGAN GAYA DAN GERAK MELALUI MODEL COOPERATIVE LEARNING KELAS VI SDN PABERASAN 1 SUMENEP
}

\author{
Luluk Aziza \\ Universitas Wijaya Kusuma Surabaya \\ lulukaziza01@gmail.com
}

\begin{abstract}
Abstrak
Tujuan peneliti ini adalah untuk mendeskripsikan penerapan model cooperative learning dalam meningkatka aktivitas memahami hubungan antara gaya dan geraksiswa kelas VI SDN Paberasan 1 Sumenep. Berdasarkan hasil penelitian, maka dapat disimpulkan bahwa kegiatan pembelajaran Ilmu Pengetahuan Alam (IPA) dalam materi hubungan gaya dan gerak melalui model cooperative learning sangat membantu siswa dalam pembelajaran Ilmu Pengetahuan Alam (IPA). Penerapan model cooperative learning dengan menentukan kelompok secara heterogen kemudian guru menjelaskan tugas-tugas setiap kelompok, guru memberikan waktu untuk melakukan diskusi, siswa mempresentasikan hasil kelompok masing-masing. Guru menjelaskan semua jawaban dari siswa dan memberikan kesimpulan. Dengan menggunakan model cooperative learning untuk memudahkan siswa memahami materi yang diberikan oleh guru. Dengan menggunakan model cooperative learning hasil belajar siswa meningkata. Hasil tersebut dibuktikan dengan adanya respon siswa pada setiap siklus bertambah aktif dan nilai siswa rata-rata meningkat dari 60,5 sampai 82 dengan tingkat ketuntasan mencapai $90 \%$ yang pada mulanya untuk siklus I hanya mencapai $45,5 \%$.
\end{abstract}

Kata Kunci: Gaya, Gerak, Model Cooperative Learning

\begin{abstract}
The aim of this research is to describe the application of the cooperative learning model in increasing the activity of understanding the relationship between force and movement of the VI grade students of SDN Pabrasi 1 Sumenep. Based on the results of the research, it can be concluded that the learning activities of Natural Sciences (IPA) in the material of the relationship of force and motion through the cooperative learning model greatly help students in learning Natural Sciences (IPA). The application of the cooperative learning model by determining the groups heterogeneously then the teacher explains the tasks of each group, the teacher gives time to hold discussions, students present the results of their respective groups. The teacher explains all the answers from students and provides conclusions. By using a cooperative learning model to make it easier for students to understand the material provided by the teacher. By using the cooperative learning
\end{abstract}


model, student learning outcomes improve. These results are evidenced by the presence of student responses in each cycle getting more active and the average student score increased from 60.5 to 82 with a completeness level reaching $90 \%$ which initially for cycle I only reached $45.5 \%$.

Keywords: Style, Motion, Cooperative Learning Model

\section{PENDAHULUAN}

Pendidikan adalah proses membantu peserta didik agar berkembang secara optimal, yaitu berkembang setinggi mungkin, sesuai dengan potensi dan sistem nilai yang dianutnya dalam masyarakat (Taufiq, 2011). Pendidikan memiliki konsep tripusat pendidikan dicetuskan oleh ki Hajar Dewantara sebagai salah satu prinsip pendidikan Taman Siswa (Surya, 2005). Secara harfiah, tripusat pendidikan dapat diartikan sebagai tiga tempat yang dianggap menjadi pusat berlangsungnya pendidikan, baik secara formal, nonformal maupun informal. Ketiga tempat tersebut adalah keluarga, sekolah dan masyarakat mempunyai peran masing-masing, Namun ketiganya saling berkaitan.

Secara alami kita ketahui bahwa pendidikan pertama terjadi dalam keluarga. Anak lahir dan dibesarkan dalam keluarga. Kehidupan dalam keluarga tidak dapat dipisahkan dari kehidupan masyarakat sekitarnya. Anak yang tumbuh dan besar dalam keluarga serta bergaul dengan teman-teman sebaya dari masyarakat sekitar, kemudian memasuki dunia baru, yaitu dunia sekolah. Kehidupan sekolah memberi warna tersendiri dalam perkembangan anak. Oleh karena itu, keluarga, sekolah dan masyarakat dianggap sebagai tiga tempat utama yang menentukan arah perkembangan seorang anak. Sejalan dengan pemikiran diatas maka berbagai masalah pendidikan yang muncul, seperti putus sekolah, anak yang suka bolos. Sekolah yang sering dituduh sebagai sumber masalah tentu tidak dapat menangani masalah tersebut tanpa kerja sama dari keluarga dan masyarakat. Namun tentu dapat kita pahami bahwa tidak semua orang mempunyai pemahaman yang samatent ang pendidikan. Masih banyak yang beranggapan bahwa sekolah merupakan penanggung jawab utama pendidikan anak.

Anak yang masih duduk dibangku sekolah dasar minim akan pengetahuan tentang pe lajaran khususnya pelajaran IPA yang banyak dimanfaat untuk sehari-hari. Di jenjang sekolah dasar anak diupayakan dapat belajar IPA dengan serius karena IPA merupakan cabang pengetahuan yang berawal dari fenomena alam. IPA didenifisikan sebagai sekumpulan pengetahuan tentang objek dan fenomena alam yang diperoleh dari hasil pemikiran dan penyelidikan ilmuwan yang dilakukan dengan keterampilan 
berekperimen. IPA merupakan cabang pengetahuan yang dibangun berdasarkan pengamatan dan klasifikasi data, dan biasanya disusun dan diverifikasi dalam hukumhukum yang bersifat kuantitaif, yang melibatkan aplikasi penalaran matematis dan analisis data terhadap gejala-gejala alam. Pada hakikatnya ipa merupakan ilmu pengetahuan tentang gejalah alam yang dituangkan berupa fakta, konsep, prinsip dan hukum yang teruji kebenrannya (Chamida, 2011).

Ilmu Pengetahuan Alam (IPA) sangat penting untuk dikuasai dan dimanfaatkan dalam sehari-hari, bahkan di terapkan dalam kehidupannya. Tetapi siswa menganggap IPA merupakan pelajaran yang sulit untuk dipahami karena banyak materi sehingga membuat anak bosan dengan pelajaran ipa. Bahkan membuat sebagian anak mengalami kegagalan dalam mata pelajaran ini untuk mendapat nilai yang baik saat evaluasi yang diberikan oleh guru (dilihat dari nilai-nilai harian dan tugas-tugas). Ilmu pengetahuan alam merupakan pengetahuan ilmiah, yaitu pengetahuan yang telah mengetahui uji kebenaran melalui metode ilmiah, dengan ciri: objektif, metodik, sistimatis, universal, dan tentatif.

Pembelajaran IPA di sekolah, merupakan salah satu pelajaran yang sulit untuk dipahami dan diterapkan oleh siswa. Oleh karena itu dalam pembelajaran IPA d iperlukan suatu metode atau model pembelajaran yang bervariasi karena pada kenyataaannya yang terjadi penguasaan siswa terhadap materi IPA sangat minim jika dibandingkan dengan pelajaran yang lainnya. Adanya pelajaran IPA di sekolah dasar untuk mendorong siswa menguasai materi, prinsip-prinsip dan konsep-konsep untuk bisa dimanfaatkan dalam sehari-hari atau untuk orang lain. Memberikan pelajaran IPA dengan menggunakan metode ceramah belum tentu konsep yang diberikan bisa diterimah oleh siswa bahkan akan menimbulkan salah konsep. Untuk itu perlu diperlukan interaksi mengajar yang baik antara guru dan siswa dalam proses belajar dan mengajar.

Terjalinnya komunikasi dan interaksi yang baik antar guru dan siswa, maka guru memperhatikan kesiapan intelektual siswa serta pemilihan metode atau model pembelajaran yang cocok untuk materi yang akan diajarkan dan sesuai dengan kemampuan siswanya. Dengan penggunaan model pembelajaran dalam pengajaran IPA diharapkan dapat mempermudah siswa untuk menerima dan memahami IPA. Melihat fenomena tersebut, maka perlu diterapka suatu sistem pembelajaran yang melibatkan siswa aktif dalam kegiatan belajar dan mengajar, untuk meningkatkan prestasi belajar IPA di setiap jenjang pendidikan,

Tugas seorang guru adalah menuntun, membimbing dan mentransfer ilmunya sesuai dengan pengalamanya mengajar yang membuat siswanya berprestasi. Yang menekankan siswa aktif dan tidak hanya mengandalkan guru untuk mendapatkan ilmunya. Dari pengamatan yang penulis lakukan terdapat suatu permasalahan yang terjadi dalam proses belajar mengajar tepatnya di SDN Paberasan 1 Sumenep pada materi gaya dan energi di kelas VI penguasaan siswa terhadap pelajaran IPA masih tergolong rendah, 
berdasarkan pengamatan penulis bahwa proses pembelajaran IPA di SDN Paberasan 1 Sumenep khususnya materi hubungan gaya dan gerakbelum menunjukkan ketuntasan yang diharapkan. Dikarenakan model atau cara mengajarnya berpusat pada guru atau siswa tidak terlibat aktif dalam pembelajaran sehingga hasil belajar siswa yang di dapatkan kurang maksimal atau siswa kurang bersemangat dalam mengikuti pelajaran IPA khususnya di pelajaran gaya dan energi. Menurut pengamatan penulis rata-rata nilai IPA siswa kelas VI SDN Paberasan 1 Sumenep pada semester II tahun pelajaran 2014-2015 yaitu 50\% dan nilai rata-rata siswa tes awal yaitu $45 \%$ menunjukkan bahwa prestasi siswa pada pelajaran IPA khususnya pada pokok bahasan hubungan gaya dan gerak masih tergolong rendah karena masih dibawah standar minimal yaitu 65\%. Pada umumnya proses pembelajaran yang digunakan adalah dengan menggunakan model pembelajaran konvensional yakni tanya jawab, ceramah, pemberian tugas dan pembelajaran di dominasi oleh guru dan siswa tidak dilibatkan, serta guru tidak memberikan peluang untuk siswa untuk menuangkan ide atau pendapatnya dalam pembelajaran IPA.

Banyak model yang bisa digunakan dalam proses pembelajaran yang digunakan dalam menyajikan suatu materi pembelajaran. Untuk pokok bahasan hubungan antara gaya dan gerak menggunakan pendekatan faktual melalui model cooperative learning. Model cooperative learning merupakan suatu cara mengajar yang dilakukan oleh guru di dalam kelas, didalam metode ini setiap individu aktif dalam memcahkan masalah, tukar-menukar pengalaman dan tular-menukar informasi dalam kelompok kerja masing-masing. Untuk itu peneliti ingin mengetahui hasil prestasi siswa jika menggunakan model cooperative learning dalam pembelajaran IPA.

Berdasarkan pemaparan yang telah disebutkan penulis tertarik mengambil judul penelitian "Peningkatan Kemampuan Memahami Hubungan Gaya dan Gerak melalui Model Cooperative Learningkelas VI SDN Paberasan 1 Sumenep"

\section{METODE}

Penelitian dilaksanakan di SDN Paberasan I Kecamatan Sumenep Kabupaten Sumenep. Jln Raya Gapura No 110 Desa Paberasan. Subyek penelitian ini yaitu 43 siswa Kelas VIterdiri dari 20 laki-laki dan 23 perempuan. Data penelitian adalah sesuatu yang diketahui atau di anggap. Diketahui, artinya sesatu yang terjadi sebagai fakta empirik (bukti yang ditemukan secara empiris melalui penelitian).

Jenis analisis data yang digunakan dalam penelitian ini adalah analisis data deskriptif. Adapun tahapan analisis yang akan dilakukan adalah:

a. Analisis Kegiatan Pembelajaran

Data tentang bagaimana proses pembelajaran di kelas berlangsung, dan kemudian dianalisis dengan menggunakan statistik deskriptif. Proses pembelajaran yang diamati adalah meliputi: bagaimanakah pembelajaran telah dilaksanakan oleh guru di kelas, 
bagaimanakah aktivitas murid saat pelajaran berlangsung dengan meggunakan metode ceramah, bagaimana hasil yang diperoleh sebelum penggunaan model cooperative learning pada pembelajaran bidang studi Ilmu Pengetahuan Alam (IPA).

b. Penganalisisan Respon Siswa

Respon yang dimaksud adalah tanggapan dan pemahaman siswa terhadap pembelajaran yang telah dilaksanakan. Untuk mengumpulkan data tersebut alat bantu yang digunakan adalah dengan cara menggunakan daftar pertanyaan untuk dijawab secara tertulis oleh siswa (angket tertutup). Dianalisis dengan menggunakan persentase yaitu banyaknya siswa yang berhasil mencapai target hasil belajar yang diharapkan guru dibagi dengan jumlah siswa keseluruhan dikali $100 \%$.dan mencampai nilai kkm yaitu 70. Menggunakan rumus :

$$
\mathrm{S}=\underline{\mathrm{R}} \mathrm{N} 100
$$

Keterangan :

$\mathrm{S}=$ Nilai yang diharapkan (dicari)

$\mathrm{R}=$ Jumlah skor dari item atau soal yang dijawab benar

$\mathrm{N}=$ Skor maksimum dari tes tersebut

Sumber : (M. Ngalim Purwanto, 2009)

c. Penganalisisan data observasi

Lembar observasi disusun untuk mengetahui segala aktivitas guru yang dilakukan oleh guru maupun siswa, yang ditunjukkan dengan kriteria-kriteria aktivitas. Setiap aktivitas tersebut diberikan poin-poin kemudian peneliti menggunakan rumus untuk menghitung aktivitas guru dan siswa selam proses pembelajaraan berlangsung tersebut dengan rumus sebagai berikut :

$$
\begin{aligned}
& \mathrm{P}=\underline{\text { Frekuensi aktivitas }} \text { X } 100 \% \\
& \text { freukensi aktivitas keseluruhan }
\end{aligned}
$$

Aktivitas belajar diukur dengan menggunakan tingkatan katagori sebagai berikut :
1. $85 \%-100 \%$
: sangat baik
(A)
2. $70 \%-84 \%$
: baik
3. $55 \%-69 \%$
: cukup
4. $40 \%-54 \%$
: kurang baik
5. $0 \%-39 \%$
: sangat kurang (E)

Sumber : Dephikbud (Rahman Felani,2007) 
Sebelum dilaksanakan pengumpulan data diperlukan instrumen yang akan dijadikan bahan dalam penelitian secara tepat. Maka dengan ini peneliti secara terperinci menggunakan instrumen sebagai berikut:

1. Format observasi keterlaksanaan proses belajar mengajar dengan metode ceramah.

2. Lembar soal berupa soal obyektif terdiri dari 5 soal yang berisi materi pokok hubungan antara gaya dan gerak, tes tulis dilakukan pada tiap siklus.

Jenis penelitian yang dipilih dalam penelitian ini adalah penelitian tindakan kelas (PTK) dengan 2 siklus. Setiap siklus terdiri dari perencanaan, pelaksanaan, observasi dan refleksi. Konsekuensi logis memilih jenis penelitian tindakan kelas adalah kehadiran penelitian di lapangan. Dalam penelitian ini peneliti bertindak sebagai pelaksana tindakan, pengumpul data, penganalisis data dan pelapor hasil penelitian, oleh karena itu kehadiran peneliti dalam lokasi dan proses peneliti mutlak diperlukan.

\section{HASIL PENELITIAN DAN PEMBAHASAN}

\section{Hasil Penelitian}

\section{Pra Siklus}

Pelaksanaan tindakan I dimulai dengan mengadakan observasi awal yang dilakukan pada hari selasa tanggal 16 Desember 2015. Tujuannya untuk mengetahui lebih mendalam kondisi sekolah, sebagai kelas yang akan mendapat perlakuan. Kondisi tersebut mencakup kondisi fisik kelas, kondisi siswa, guru, proses pembelajaran dan kegiatan belajar mengajar dikelas serta sarana dan prasarana pendidikan yang terdapat di kelas maupun di sekolah. Pada observasi awal, kegiatan pembelajaran terdiri dari 3 tahapan, 1) Kegiatan awal, 2) Kegiatan Inti, dan 3) Penutup. Pada kegiatan awal yang berupa appersepsi, siswa diajak tanya jawab tentang materi yang akan dibahas, yang akhirnya mengaitkan dengan materi inti. Sedangkan pada kegiatan inti dalam pembelajaran banyak menggunakan metode ceramah tanpa menggunakan media apapun kecuali buku pelajaran Ilmu Pengetahuan Alam (IPA). Guru lebih banyak menerangkan dengan menggunakan metode ceramah dalam menjelaskan materi sehingga siswa hanya mendapatkan materi yang abstrak dan kegiatan belajar mengajar terfokus kepada guru. Selain itu, keterlibatan siswa masih tampak kurang optimal, ini terlihat dari kepasifan dan kebingungan siswa dalam mengikuti dan memahami pelajaran yang disampaikan guru. Adapun kegiatan penutup siswa diberi tugas mengerjakan soal atau evaluasi.

Pada refleksi awal melalui observasi dapat ditemukan beberapa kelebihan dan kekurangan pada kegiatan pembelajaran. Kelebihan-kelebihan tersebut antara lain:

1. Proses pembelajaran telah diselenggarakan secara terstruktur dan sistematis sesuai dengan rencana pelaksanaan pembelajaran (RPP)

2. Guru banyak menyampaikan informasi tentang materi dengan menggunakan metode ceramah dalam setiap kegiatan pembelajaran. 
Sedangkan beberapa kekurangan dalam proses pembelajaran yang ditemukan adalah :

1. Guru banyak menghabiskan waktu pembelajaran (sekitar 65-70\%) hanya menjelaskan secara verbal konsep yang abstrak tanpa dibantu dengan sarana dan atau media penunjang yang memadai,

2. Siswa cenderung bersifat pasif dan tidak berani menjawab pertanyaan guru karena kurang antusias mengikuti pelajaran, merasa kebingungan memahami konsep yang dijelaskan guru.

Selama observasi awal ini juga, siswa belum menunjukkan perilaku yang diharapkan. Siswa lebih banyak yang pasif dalam proses kegiatan belajar mengajar, bahkan hanya $10 \%$ yang bisa menjawab pertanyaan dari guru diakhir pembelajaran ini disebabkan karena guru kurang memberikan peluang siswa untuk aktif dan praktek langsung untuk memudahkan siswa mengerti dan mengingat materi yang diberikan oleh guru.

\section{Siklus I}

Berdasarkan hasil pengamatan yang diperoleh dari observasi awal, peneliti memberi tindakan siklus I yang dilaksanakan pada hari selasa 16 desember 2015dalam kegiatan ini dibagi menjadi beberapa tahapan sebagai berikut :

\section{Perencanaan}

Tahap perencanaan meliputi menyiapkan lembar kerja siswa (LKS) sesuai dengan materi yang akan dibahas yaitu hubungan antara gaya dan gerak. Selain itu juga pembuatan rencana pembelajaran dan lembar observasi pelaksanaan pembelajaran.

Sebelum mengawali pelajaran terlebih dahulu guru memberikan penjelasan tujuan pembelajaran yang akan dibahas. Kemudian dilanjutkan dengan apersepsi dan pemberian pertanyaan guru terhadap siswa sebagai stimulus awal kesiapan siswa dalam mengikuti pelajaran.

\section{Pelaksanaan}

1. Pada awal pembelajaran yang dilakukan guru, menjelaskan tujuan pembelajaran

2. Siswa membuka buku paket IPA yang dimiliki

3. Guru menjelaskan tentang hubungan gaya dan gerak dalam kehidupan sehari-hari dan menjelaskan faktor-faktor yang mempengaruhinya.

4. Diakhir pembelajaran guru memberikan kuis untuk menguji kemampuan siswa dalam memahami materi yag diberikan oleh guru. 


\section{Observasi}

Hasil observasi siklus I terlihat pada tabel berikut ini:

Tabel Rekapitulasi Hasil Tes Formatif Siswa pada Siklus I

\begin{tabular}{|c|l|c|}
\hline No & \multicolumn{1}{|c|}{ Uraian } & Hasil Siklus I \\
\hline 1 & Nilai rata-rata tes formatif & 60,5 \\
2 & Jumlah siswa yang tuntas belajar & 27 \\
3 & Persentase ketuntasan belajar & $45,5 \%$ \\
\hline
\end{tabular}

\section{Refleksi}

Dari Tabel. di atas dapat dijelaskan bahwa dengan menerapkan pembelajaran kontekstual model pengajaran berbasis masalah diperoleh nilai rata-rata prestasi belajar siswa adalah 60,5 dan ketuntasan belajar mencapai 45,5\% atau ada 27 siswa dari 43 siswa sudah tuntas belajar. Hasil tersebut menunjukkan bahwa pada siklus pertama secara klasikal siswa belum tuntas belajar, karena siswa yang memperoleh nilai $\geq 65$ hanya sebesar $45,5 \%$ lebih kecil dari persentase ketuntasan yang dikehendaki yaitu sebesar $85 \%$. Hal ini disebabkan karena menggunakan model cooperative learning tampa menggunakan media.

\section{Siklus II}

\section{Perencanaan}

Kekurangan-kekurangan yang ada pada pertemuan kedua siklus I , dibahas oleh peneliti untuk mencari jalan keluarnya. Pada pertemuan pertama siklus I, peneliti sudah dapat menguasai kelas namun beberapa kali masih nampak siswa kurang konsentrasi pada pembelajaran, sedangkan pada pembelajaran ini seharusnya respon dan daya tangkap para siswa lebih bisa diarahkan untuk menentukan perolehan hasil pembelajaran yang optimal.

Pertemuan Siklus II dilaksanakan pada hari jumat 19 desember 2014. Pada awal pertemuan, peneliti menanyakan apakah ada pertanyaan atau tidak, kemudian peneliti mengajukan beberapa pertanyaan dan hasilnya $70 \%$ siswa merespon pertanyaan.

\section{Pelaksanaan}

Dalam siklus II ini, peneliti menjelaskan materi yang akan disampaikan kemudian peneliti membentuk kelompok heterogen untuk memudahkan siswa memahami dalam materi hubungan gaya dan gerak dengan praktek langsung bersama teman kelompok. Peneliti memberikan waktu 20 menit untuk berdiskusi dan mengamati langsung benda yang sudah dibawah dari rumahnya. Setelah itu salah satu perwakilan kelompok maju untuk membaca hasil diskusinya kepada teman-temanya secara bergiliran hingga semua kelompok perwakilannya maju semua. Diakhir pelajaran peneliti memberikan soal untuk mengukur hasil pemahaman siswa. 


\section{Observasi}

Hasil observasi siklus II terlihat pada tabel berikut ini:

Tabel Rekapitulasi Hasil Tes Formatif Siswa pada Siklus II

\begin{tabular}{|c|l|c|}
\hline No & \multicolumn{1}{|c|}{ Uraian } & Hasil Siklus II \\
\hline 1 & Nilai rata-rata tes formatif & 82 \\
2 & Jumlah siswa yang tuntas belajar & 35 \\
3 & Persentase ketuntasan belajar & $90 \%$ \\
\hline
\end{tabular}

\section{Refleksi}

Berdasarkan Tabel diatas diperoleh nilai rata-rata tes formatif sebesar 82 dan dari 35 siswa yang telah tuntas sebanyak 43 siswa dan 8 siswa belum mencapai ketuntasan belajar. Maka secara klasikal ketuntasan belajar yang telah tercapai sebesar $90 \%$ (termasuk kategori tuntas). Hasil pada siklus II ini mengalami peningkatan lebih baik dari siklus I. Adanya peningkatan hasil belajar pada siklus II ini dipengaruhi oleh adanya peningkatankemampuan siswa mempelajari materi pelajaran yang telah diterapkan selama ini. Disamping itu dengan adanya metode pembelajaran ini siswa dapat bertanya dengan sesama temanya, dan ternyata dari proses bertanya antar siswa ini, siswa lebih mudah menerima penjelasan dari temannya yang lebih paham tentang materi pelejaran tersebut.

Setelah siklus II selesai dilaksanakan, guru atau peneliti mengadakan refleksi akhir. Dari pengamatan peneliti, secara umum pembelajaran pada siklus II lebih baik daripada siklus I. Beberapa kelebihan pada siklus II ini adalah sebagai berikut :

1. Peneliti dapat menguasai kelas, serta keaktifan siswa sudah mencapai 90 $\%$.

2. Pembelajaran yang dilakukan kepada para siswa semakin lebih efektif dengan lebih menekankan pada cara penggunaan metode pembelajaran dengan bantuan media /sumber belajar.

\section{PEMBAHASAN HASIL PENELITIAN}

Model pembelajaran cooperative learning merupakan suatu cara mengajar yang dilakukan guru di dalam kelas, di dalam model ini setiap individu terlihat aktif dalam memecahkan masalah, tukar menukar pengalaman dan tukar menukar informasi dalam kelompok kerja masing-masing (Nasution, 2007). Berdasarkan data pada tabel tersebut didepan, bahwa nilai pada siklus II meningkat sampai 90\%. Hasil data belajar siswa 


\begin{tabular}{|c|c|c|c|}
\hline No & Nama Siswa & Siklus I & Siklus II \\
\hline 1. & Ari Fadillah & 60 & 100 \\
\hline 2 & Agung Aprianto & 70 & 90 \\
\hline 3 & Achmad Rizki Maulana & 50 & 60 \\
\hline 4 & Ahsanul Kholiqin & 65 & 100 \\
\hline 5 & Anisa Nur Radiah & 80 & 80 \\
\hline 6 & Anendia Selviana Putri & 50 & 70 \\
\hline 7 & Awang Abdul Latif & 68 & 80 \\
\hline 8 & Ayu Viva Dian Wahyuni & 55 & 100 \\
\hline 9 & Afifatur Rofi'ah & 50 & 70 \\
\hline 10 & Azka Nanda Pita Loka & 89 & 89 \\
\hline 11 & Boyke Rosandi & 60 & 80 \\
\hline 12 & Dina Khoirina & 90 & 90 \\
\hline 13 & Dimas Iqbal Pratama & 60 & 60 \\
\hline 14 & Eka Prasetya Nugrah & 65 & 85 \\
\hline 15 & Fadlur Rahman & 50 & 100 \\
\hline 16 & Hudrotul Izfa'lina & 76 & 76 \\
\hline 17 & Hafidatul Laily & 57 & 57 \\
\hline 18 & Indah Safitri & 80 & 80 \\
\hline 19 & Irgi Priantito & 50 & 100 \\
\hline 20 & Ifa Mariana & 60 & 90 \\
\hline 21 & Leilya Putri Ramadani & 50 & 70 \\
\hline 22 & Khoirul Wafi & 55 & 55 \\
\hline 23 & Maulana Malik Abdillah & 45 & 100 \\
\hline 24 & $\begin{array}{lll}\text { Moh Romiz Aprillia } \\
\text { Annur }\end{array}$ & 50 & 50 \\
\hline 25 & Mayse Putri Anabela & 70 & 100 \\
\hline 26 & Alwi Almaliki & 60 & 90 \\
\hline 27 & Husnui Robet & 79 & 80 \\
\hline 28 & $\begin{array}{l}\text { Moh Tamzilul Wared Al } \\
\text { Fayat }\end{array}$ & 54 & 54 \\
\hline 29 & Siti Aisyah & 45 & 80 \\
\hline 30 & Nur Alivia & 65 & 90 \\
\hline 31 & Nur Fadhilatul Jannah & 50 & 50 \\
\hline 32 & Nur Fatila Sari & 45 & 100 \\
\hline 33 & Nur Dina Koyyimah & 70 & 70 \\
\hline 34 & Riko Alfarosi & 56 & 90 \\
\hline
\end{tabular}


Peninglatan Kemampuan Memahani Hubugan Gaya dar Geral melahi Metode Cooperative learring

\begin{tabular}{|c|l|c|c|}
\hline 35 & Rifqi Lestari & 45 & 100 \\
\hline 36 & Selly Hikmatur Rohma & 65 & 80 \\
\hline 37 & Sulis Setya Ningsi & 70 & 100 \\
\hline 38 & Sarep Hidayatullah & 80 & 80 \\
\hline 39 & Mohammad Firman & 55 & 90 \\
\hline 40 & Sarif Khoirunnas & 60 & 90 \\
\hline 41 & $\begin{array}{l}\text { Wafiko Nabilatul } \\
\text { Fadiyah }\end{array}$ & 50 & 100 \\
\hline 42 & $\begin{array}{l}\text { Wafiqoh Dwi Oktaviana } \\
\text { Putri }\end{array}$ & 55 & 55 \\
\hline 43 & Khoirunnisak Maisyuro & 45 & 100 \\
\hline & JUMLAH & 2604 & 3521 \\
\hline & RATA-RATA & 60,5 & 82 \\
\hline & $\begin{array}{l}\text { PROSENTASE } \\
\text { KETUNTASAN }\end{array}$ & $45,5 \%$ & $90 \%$ \\
\hline
\end{tabular}

ditunjukkan bahwa para siswa menganggap bahwa pola pembinaan tentang pembelajaran Ilmu Pengetahuan Alam (IPA) dengan menggunakan model pembelajaran cooperative learningtermasuk hal baik yang perlu terus dikembangkan. Pelaksanaan model ini mengadaptasi model sebelumnya yang pernah dilaksanakan pada beberapa pembelajaran, sehingga beberapa para siswa tidak terlihat mengalami kesulitan dalam beraktifitas selama pembelajaran berlangsung. Oleh sebab itu beberapa para siswa merasa bahwa Ilmu Pengetahuan Alam (IPA) dengan menggunakan model pembelajaran cooperative learnining membantu dalam memahami tentang pembelajaran Ilmu Pengetahuan Alam (IPA) dengan menggunakan media ketapel, kursi dll hal ini ditunjukkan dari sekitar $90 \%$ menyatakan demikian sedang sisanya tidak. Beberapa hal yang menyebabkan para siswa tidak kesulitan cukup menunjukkan bahwa tahapan pembelajaran ini tidak sesulit yang dibayangkan namun perlu kesungguhan.

Faktor lain yang menyebabkan hal diatas adalah disebabkan kondisi pembelajaran yang menyenangkan bagi para guru, hal ini dinyatakan sekitar $80 \%$, oleh sebab itulah sekitar $80 \%$ para siswa merasa bahwa fasilitas pembelajaran cukup memadai sehingga menumbuhkan sikap senang selama pembelajaran berlangsung.

Sekitar $80 \%$ para siswa merasakan bahwa alokasi waktu yang diberikan dalam mengikuti pembelajaran cukup memadai. Hal ini turut ditunjang dengan setting forum yang baik sehingga $80 \%$ para siswa membenarkan hal ini, dan beberapa para siswa menyatakan bahwa suasana ruang pembelajaran demikian menyenangkan. Hal ini menunjukkan bahwa pembinaan pembelajaranIlmu Pengetahuan Alam (IPA) dengan menggunakan model pembelajaran khususnya model cooperative learning. 
Dalam aspek penguasaan materi dan metode fasilitator dinyatakan oleh para guru terkategori baik dengan berturut $80 \%$ dan $80 \%$ menyatakan hal ini. Sedangkan dalam aspek kesesuaian latar belakang pendidikan terhadap materi dan metode yang digunakan seluruhnya menyatakan bahwa semuanya sesuai. Berkaitan dengan aspek kesesuaian metode dan media yang digunakan sekitar $80 \%$ dan $88 \%$ menyatakan hal tersebut.

\section{KESIMPULAN}

Berdasarkan hasil penelitian, maka dapat disimpulkan bahwa kegiatan pembelajaran Ilmu Pengetahuan Alam (IPA) dalam materi hubungan gaya dan gerak melalui model cooperative learning sangat membantu siswa dalam pembelajaran Ilmu Pengetahuan Alam (IPA).

1. Penerapan model cooperative learning dengan menentukan kelompok secara heterogen kemudian guru menjelaskan tugas-tugas setiap kelompok, guru memberikan waktu untuk melakukan diskusi, siswa mempresentasikan hasil kelompok masing-masing. Guru menjelaskan semua jawaban dari siswa dan memberikan kesimpulan. Dengan menggunakan model cooperative learning untuk memudahkan siswa memahami materi yang diberikan oleh guru.

2. Dengan menggunakan model cooperative learning hasil belajar siswa meningkata. Hasil tersebut dibuktikan dengan adanya respon siswa pada setiap siklus bertambah aktif dan nilai siswa rata-rata meningkat dari 60,5 sampai 82 dengan tingkat ketuntasan mencapai $90 \%$ yang pada mulanya untuk siklus I hanya mencapai $45,5 \%$.

\section{DAFTAR PUSTAKA}

Chamida, D. dkk. (2011). Landasan Pendidikan IPA. Zhaf Production. M. Ngalim Purwanto. (2009). Ilmu Pendidikan Teoritis dan Praktis. PT Remaja

Rosdakarya.

Nasution, N. (2007). Pendidikan IPA di SD. Universitas Terbuk.

Surya, dkk. (2005). Kapita Selekta Kependidikan SD. Universitas Terbuk.

Taufiq, A. dkk. (2011). Pendidikan Anak di SD. Universitas Terbuk.

Chamida, D. dkk. (2011). Landasan Pendidikan IPA. Zhaf Production.

M. Ngalim Purwanto. (2009). Ilmu Pendidikan Teoritis dan Praktis. PT Remaja

Rosdakarya.

Nasution, N. (2007). Pendidikan IPA di SD. Universitas Terbuk.

Surya, dkk. (2005). Kapita Selekta Kependidikan SD. Universitas Terbuk.

Taufiq, A. dkk. (2011). Pendidikan Anak di SD. Universitas Terbuk. 